\title{
Targeting the hallmarks of cancer: the effects of silibinin on proliferation, cell death, angiogenesis, and migration in colorectal cancer
}

\author{
Saba Sameri ${ }^{1}$, Chiman Mohammadi ${ }^{1}$, Mehrnaz Mehrabani ${ }^{2}$ and Rezvan Najafi ${ }^{*}$
}

\begin{abstract}
Background: Silibinin, as a chemopreventive agent, has shown anti-cancer efficacy against different types of cancers. In the present study, we investigated the anti-cancer activities of silibinin on CT26 mouse colon cell line.

Methods: CT26 cells were treated with different concentrations of silibinin. To examine the cytotoxic effect of silibinin on proliferation, apoptosis, autophagy, angiogenesis, and migration, MTT, colony-forming assay, Annexin V/ PI flow cytometry, RT-qPCR, and Scratch assay were used.

Results: Silibinin was found to significantly reduce CT26 cells survival. Furthermore, silibinin strongly induced apoptosis and autophagy by up-regulating the expression of Bax, Caspase-3, Atg5, Atg7 and BECN1 and downregulating $B C-$-2. Silibinin considerably down-regulated the expression of COX-2, HIF-1a, VEGF, Ang-2, and Ang-4 as well as the expression of MMP-2, MMP-9, CCR-2 and CXCR-4.
\end{abstract}

Conclusions: The present study revealed that silibinin shows anticancer activities by targeting proliferation, cell survival, angiogenesis, and migration of CT26 cells.

Keywords: Colorectal cancer, Silibinin, Angiogenesis, Autophagy, Apoptosis, Migration

\section{Introduction}

The transformation of human normal cells into malignant tumors is a multistep process, called carcinogenesis, which requires the accumulation of a variety of genetic and epigenetic aberrations. These hallmarks of cancer include the (i) constant proliferation of tumor cells, (ii) resistance to cell death, (iii) induction of angiogenesisand activation of invasion and (iv) metastasis [1].

One of the most significant hallmarks of cancer is unchecked cell proliferation of cancer cells in the absence of the external stimuli so as to enable them to have

\footnotetext{
* Correspondence: re.najafi@umsha.ac.ir; najafi2535@gmail.com ${ }^{1}$ Research Center for Molecular Medicine, Hamadan University of Medical Sciences, Hamadan, Iran

Full list of author information is available at the end of the article
}

unlimited growth, while in normal cells are able to control the number of cell divisions, tissue construction, and function [2]. Furthermore, apoptosis and autophagy, as two main mechanisms of cell death, can be repressed by the cancer cells which in turn leads to uncontrolled proliferation [1].

One more obligatory factor for tumor growth and development is angiogenesis in which the new blood vessels are formed and later lay the ground for metastasis to distant organs [3]. ence, anti-angiogenic drugs have become one of the most promising approaches for cancer treatment. Although many chemotherapeutic agents have been discovered which are effective in blocking the above-mentioned mechanisms, their high toxicities and side effects still remain a critical issue. Thus, exploring

(c) The Author(s). 2021 Open Access This article is licensed under a Creative Commons Attribution 4.0 International License, which permits use, sharing, adaptation, distribution and reproduction in any medium or format, as long as you give appropriate credit to the original author(s) and the source, provide a link to the Creative Commons licence, and indicate if changes were made. The images or other third party material in this article are included in the article's Creative Commons licence, unless indicated otherwise in a credit line to the material. If material is not included in the article's Creative Commons licence and your intended use is not permitted by statutory regulation or exceeds the permitted use, you will need to obtain permission directly from the copyright holder. To view a copy of this licence, visit http://creativecommons.org/licenses/by/4.0/. The Creative Commons Public Domain Dedication waiver (http://creativecommons.org/publicdomain/zero/1.0/) applies to the data made available in this article, unless otherwise stated in a credit line to the data. 
other therapeutic approaches with fewer possible side effects is called for. One of such approaches is chemoprevention [4].

Studies have illustrated that many phytochemicals such as silibinin, isothiocyanates, genistein, curcumin and ellagic acid have shown both radiosensitizing and chemosensitizing properties $[5,6]$. Silibinin, the major active constituent of Sylimarin, has shown promise against various types of tumors such as prostate, lung, skin, and colon, by targeting the multi-step tumorigenic events such as unrestricted proliferation, loss of cell death, and induction of angiogenesis [7-9]. However, the molecular mechanisms related with the anti-cancer properties of silibinin have not been clearly expounded.

The long period of colorectal cancer (CRC) progression from a precursor lesion, taking about 10 to 20 years, provides a unique opportunity for effective intervention to each step of carcinogenesis [10].

In the present study, we investigated the anti-cancer efficacy of Silibinin on cell proliferation, migration, angiogenesis, apoptosis, and autophagy of CT26 colorectal cancer cell line to lay the foundation for further preclinical studies in a mouse model.

\section{Materials and methods}

\section{Chemicals and cell lines}

Silibinin (chemical name: 2,3-Dihydor-3-(4-hydroxy-3methoxyphenyl)-2-(hydroxymethyl)-6-(3,5,7-trihydroxy4-oxobenzopyran-2-yl) benzodioxin) was purchased from Sigma-Aldrich. Dimethyl sulfoxide (DMSO), from Sigma, was used to prepare the stock solution of Silibinin. The following working concentration was diluted in the respective mediums and the final concentration of DMSO was $<0.1 \%(v / v)$. CT26 Colon Cancer Cell line and VERO cells as normal cell line [11-14] were obtained from National Cell Bank of Iran, Pasteur Institute (Tehran, Iran) and grown in Dulbecco's modified Eagle's medium (DMEM) and RPMI-1640 medium respectively, supplemented with 10\% fetal bovine serum (FBS; Gibco, Invitrogen) and 100 units $/ \mathrm{mL}$ streptomycin and penicillin (P/S; Gibco, Invitrogen). According to the standard culture conditions, the air was humified and its temperature was maintained at $37^{\circ} \mathrm{C}$ with $5 \% \mathrm{CO} 2$.

\section{Cell growth and viability assay}

MTT assay was used to determine the growth and viability of cells after silibinin treatments. The CT26 and VERO cells were seeded in 96-plate at the density of $5 \times$ $10^{3}$ and $6 \times 10^{3}$ cells per well respectively and afterwards incubated overnight, allowing them to attach. Based on the our previous study [15], CT26 cells were treated with different concentrations of silibinin $(0-250 \mu \mathrm{M})$ and VERO cells with the final concentration of $0-1000 \mu \mathrm{M}$ of silibinin. Following silibinin treatment for 24, 48 and
$72 \mathrm{~h}, 10 \mu \mathrm{l} \mathrm{MTT}$ was added to each well. After $3 \mathrm{~h}$ of incubation at $37^{\circ} \mathrm{C}$, the medium was removed and then $100 \mu \mathrm{l}$ of DMSO was added to each well to dissolve the resulting formazan product. The absorbance of solubilized formazan was quantified using an automatic microplate reader at $570 \mathrm{~nm}$.

\section{Colony-forming assay}

CT26 cells were treated with the dose of $50 \mu \mathrm{M}$ of silibinin and after $24 \mathrm{~h}$ incubation at $37^{\circ} \mathrm{C}$, they were detached from the plate and reseeded at a density of 400 cells per each well in a new 6-well plate. An additional 7 days of incubation was carried for cells to enable cells to form visualized colonies. The colonies were stained with $0.05 \%$ crystal violet solution (dissolved in methanol and water) and subsequently, the number of colonies was counted, using ImageJ software.

\section{Flow cytometry assay}

For investigating the different stages of apoptosis in CT26 cell line, Annexin V-FITC/ propidium iodide (PI) detection kit (MabTag, Germany) was used. After silibinin treatment with a dose of $50 \mu \mathrm{M}, 10^{5}$ cells were harvested by diluted trypsin and washed twice by $\mathrm{PBS}$. According to the manufacturer's instructions, the cells were stained and then analyzed, using Attune NxT acoustic focusing cytometer (Life technology, USA) and FlowJo software 10.

\section{RNA extraction and reverse transcription-polymerase chain reaction (RT-PCR)}

Total RNA was isolated from CT26 cells by RNX-Plus kit (Cinnagen, Tehran, Iran) after silibinin treatment with a dose of $50 \mu \mathrm{M}$ according to the manufacturer's protocol and the concentration and purity of the resulted RNA was measured by NanoDrop (Thermo Fisher Scientific, Waltham, MA). Afterwards, cDNA was synthesized from the total RNA, using the Takara kit (Kyoto, Japan). The total volume of the reaction mixture for real-time PCR was $20 \mathrm{~mL}$, containing $1 \mathrm{~mL}$ cDNA, 7 $\mathrm{mL} \mathrm{H} 2 \mathrm{O}, 10 \mathrm{~mL}$ SYBER Blue master mix (Cinnagen, Tehran, Iran), and $1 \mathrm{~mL}$ of $\mathrm{pmol} / \mathrm{mL}$ specific primers. Primer sequences used for real-time quantitative PCR are listed in Table 1. 18S ribosomal RNA (18S rRNA) was applied as an internal control gene for CT26 cells and relative expression was normalized and reported by the $2^{-\Delta \Delta \mathrm{Ct}}$ method analysis.

\section{Migration assay}

For determining the migration ability of CT26 cells, the migration assay was applied. Briefly, in a 24-well plate, $75 \times 10^{3}$ cells were seeded and incubated at $37^{\circ} \mathrm{C}$ for 48 h. Next, the culture area was scratched with a crystal pipette tip to make a linear gap in the confluent 
Table 1 Primer sequences for qRT-PCR

\begin{tabular}{|c|c|c|}
\hline Gene & Sense strand & Antisense strand \\
\hline Bax & TITGCTACAGGGTTTCATCC & TATTGCTGTCCAGTTCATCTC \\
\hline $\mathrm{Bcl}-2$ & CTCGTCGCTACCGTCGTGACTTCG & ACCCCATCCCTGAAGAGTTCC \\
\hline Caspase-3 & GAATGTCATCTCGCTCTGGTACG & CTGCTCCTITTGCTATGATCTTCC \\
\hline Beclin1 & GGCTGAGAGACTGGATCAGG & GAGAAGCAGCTTCCTGTTCTGG \\
\hline ATG5 & TGCATCAAGTTCAGCTCTTCCT & GCAATCCCATCCAGAGTTGC \\
\hline ATG7 & TGGCTGCTATTTCTGCAATG & TTCTGGATGCTGCAAAACAG \\
\hline Cox-2 & TGCTGTTCCAACCCATGTCA & TCTTGTCAGAAACTCAGGCGT \\
\hline HIF-1a & CCATTCСТCATCCATCAA & CCATCAACTCAGGTAATCCT \\
\hline Angiopoeitin-2 & CAGTTCGTTGTTCCGTCTTGTG & CCGTATAGTAATAGTGTCCAGCCATT \\
\hline Angiopoeitin-4 & TCCATCCAGTATGAGAAC & GCAGTTATCATTGTCCAT \\
\hline CXCR-4 & CATGGAAATATACACTTCGGA & TGCCCACTATGCCAGTCAAG \\
\hline CCR-2 & TGTTACCTCAGTTCATCCA & GTTCACCATCATCATAGTCAT \\
\hline MMP-2 & CCCACGAAGCCTTGTTTACC & AGCTGTTGTAAGAGGTGCCCTGGAA \\
\hline MMP-9 & CCACTAAAGGTCGCTCGGA & GAGTTGCCCCCAGTTACG \\
\hline 18srRNA & GTAACCGTTGAACCCCATT & CCATCCAATCGGTAGTAGCG \\
\hline
\end{tabular}

monolayer and then, to remove the debris, it was washed twice with PBS. Afterwards, each well was treated with different concentrations of Silibinin $(0,25,50,75 \mu \mathrm{M})$ and then the images of the culture area were taken at 24,48 and $72 \mathrm{~h}$ to determine whether cells could fill the generated gap.

\section{Statistical analysis}

SPSS 25.0 software was used for data analysis. One-way variance analysis (ANOVA), followed by Tukey-Kramer pairwise comparison, was performed to determine the significance of the difference between groups. Data were presented as the mean \pm standard error (SEM) and the $P$-value of $<0.05$ was considered statistically significant.

\section{Result}

Silibinin inhibits cell growth and proliferation of CT26 cells

MTT assay was used to determine the cytotoxic effect of silibinin on CT26 cells treated with different concentration of silibinin for 24, 48 and $72 \mathrm{~h}$. As shown in Fig. 1A, silibinin reduced the cell viability in a time- and dosedependent manner. As silibinin, in $24 \mathrm{~h}$, reached the IC50 value in approximately $50 \mu \mathrm{M}$, this dose was used in further experiments. To determine whether silibinin has toxic effect for normal cell lines, VERO cells were treated with different doses of silibinin $(0-1000 \mu \mathrm{M})$ (Fig. 1B). The results suggest that silibinin is not toxic for normal cells, showing its specific toxicity against the CRC line. Furthermore, the capacity of cells to proliferate and produce colonies, a key characteristic of cancer cells, was determined by colony-forming assay. The results, which were consistent with the results from the MTT assay, showed a significant reduction in size and number of colonies, treated with $50 \mu \mathrm{M}$ silibinin, compared to the control group (Fig. 1C). Hence, silibinin suppresses cell growth and proliferation of CT26 cells.

\section{Silibinin induces apoptosis and autophagic cell death in CT26 cells}

Flow cytometry was used to detect cell apoptosis in cells treated with silibinin, doses of 0,50 and $100 \mu \mathrm{M}$, for $24 \mathrm{~h}$. In the control group, the apoptotic rates in early and late stages of apoptosis were 6.25 and $4.89 \%$, while these rates in the cells treated with a dose of 50 were 15.1 and $5.46 \%$ and they were 36.14 and $18.5 \%$ for a dose of $100 \mu \mathrm{M}$. This clearly indicates that silibinin induced cell apoptosis in a dosedependent manner (Fig. 2A). Moreover, to find out the mechanisms involved in the apoptosis of CT26 cells, the mRNA expression of Bax, Bcl-2 and Caspase-3 were investigated in cells treated with $50 \mu \mathrm{M}$ of silibinin for $24 \mathrm{~h}$, as shown in Fig. 2B. The results showed that silibinin increased the expression of $\mathrm{Bax}$ and Caspase-3, as pro-apoptotic factors, in mRNA levels, while decreased the mRNA expression of $\mathrm{Bcl}-2$ as an anti-apoptotic factor. These all suggest that cell apoptosis can be accelerated by silibinin through inducing the initiation of mitochondrial apoptosis. As previous studies have demonstrated that silibinin could induce autophagy in several types of tumor cells [16-18], we aimed to investigate the cytotoxic 


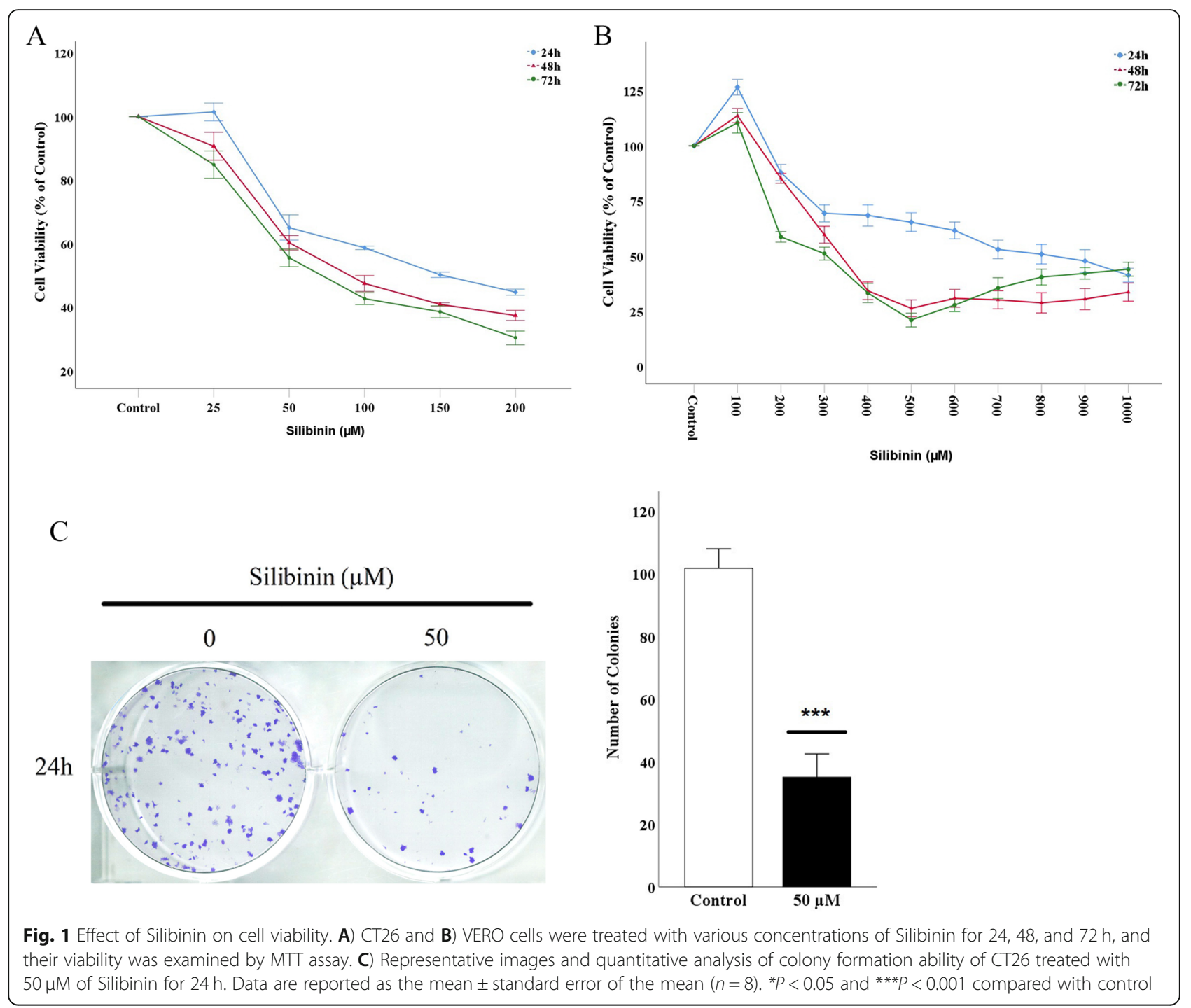

effect of silibinin on autophagy in CT26 cell line. Hence, to confirm the induction of autophagy, a set of related genes including Atg5, Atg7 and Beclin-1, which are critical for this process, were studied in this study. We found the mRNA expression of Atg5, Atg7 and BECN1 in CT26 cells was significantly increased when treated with $50 \mu \mathrm{M}$ of silibinin for $24 \mathrm{~h}$, compared to the control group (Fig. 2C).

\section{Silibinin decreases the expression of genes involved in angiogenesis}

As angiogenesis is one of the main hallmarks of cancer progression, in this study, we aimed to investigate the anti-angiogenic effect silibinin in CRC cells. Thus, quantitative real-time PCR was performed on silibinin-treated $(50 \mu \mathrm{M})$ and untreated CT26 cells and the results indicated that silibinin considerably declined the mRNA levels of HIF-1 $\alpha, C O X-2$, VEGF, Ang-2, and Ang-4, compared to the untreated group (Fig. 3).

\section{Silibinin inhibits migration of CT26 cells}

In order to determine the capacity of CT26 cells to migrate, the scratch test was applied. As shown in Fig. 4A, the cells treated with different dose of Silibinin $(0,25,50$ and $75 \mu \mathrm{M})$ for 3 consecutive days, showed different levels of migration, suggesting that silibinin could inhibit the migration of the cells in a time- and dose-dependent manner. Furthermore, for detecting the molecular mechanisms involved in the migration, the mRNA expression of MMP-2 and MMP-9, CXCR-4 and CCR-2, were measured in CT26 treated with $50 \mu \mathrm{M}$ for $24 \mathrm{~h}$. As shown in Fig. $4 \mathrm{~B}$, the expression of the above-mentioned genes showed a significant decrease, confirming the results of the scratch test. Thus, it seems that silibinin inhibits the 

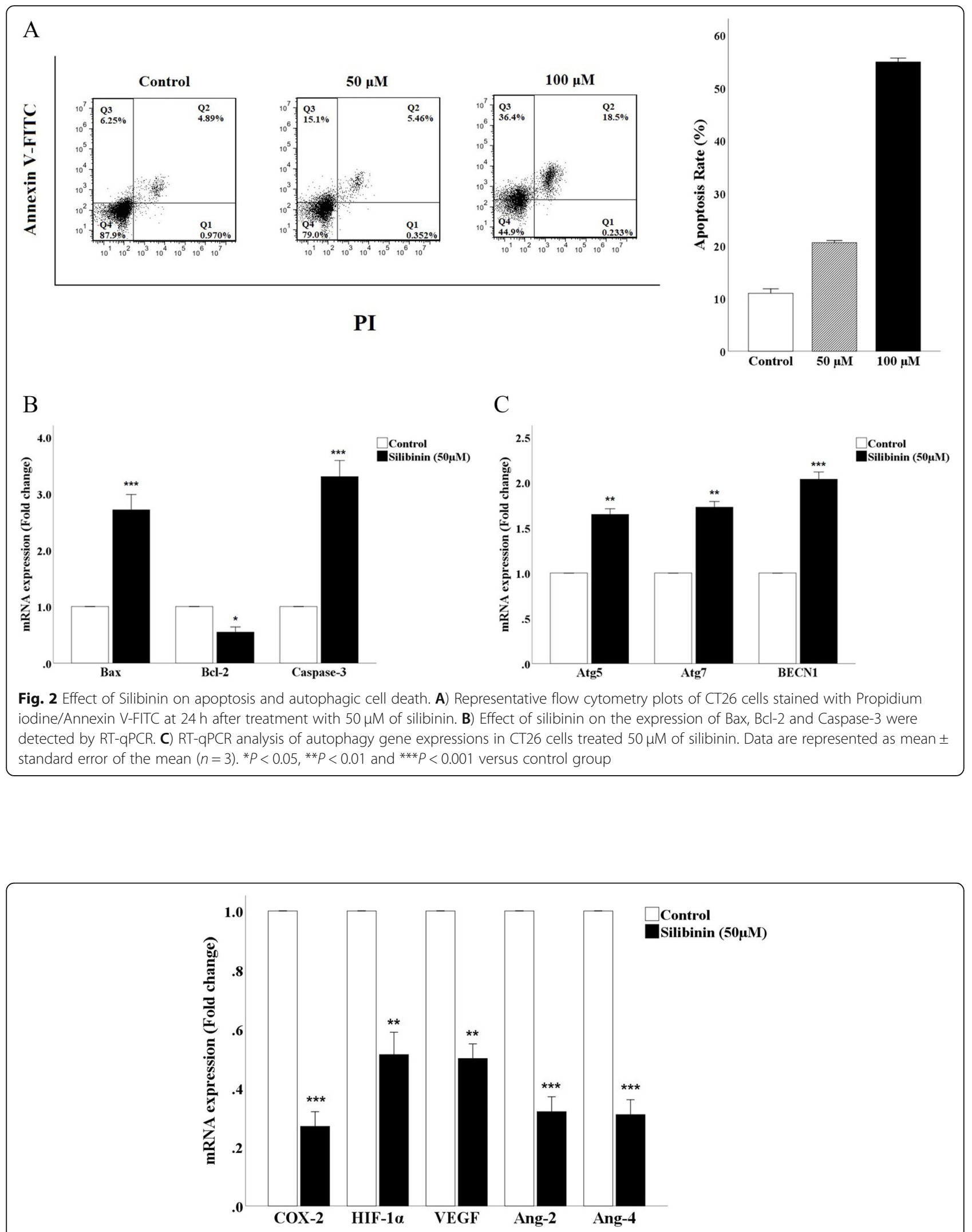

Fig. 3 Effect of silibinin on angiogenesis. CT26 cells were treated with $50 \mu \mathrm{M}$ for $24 \mathrm{~h}$, and the expression of genes was measured by RT-qPCR. Data are represented as mean \pm standard error of the mean $(n=3) .{ }^{* *} P<0.01$ and ${ }^{* *} P<0.001$ versus control group 


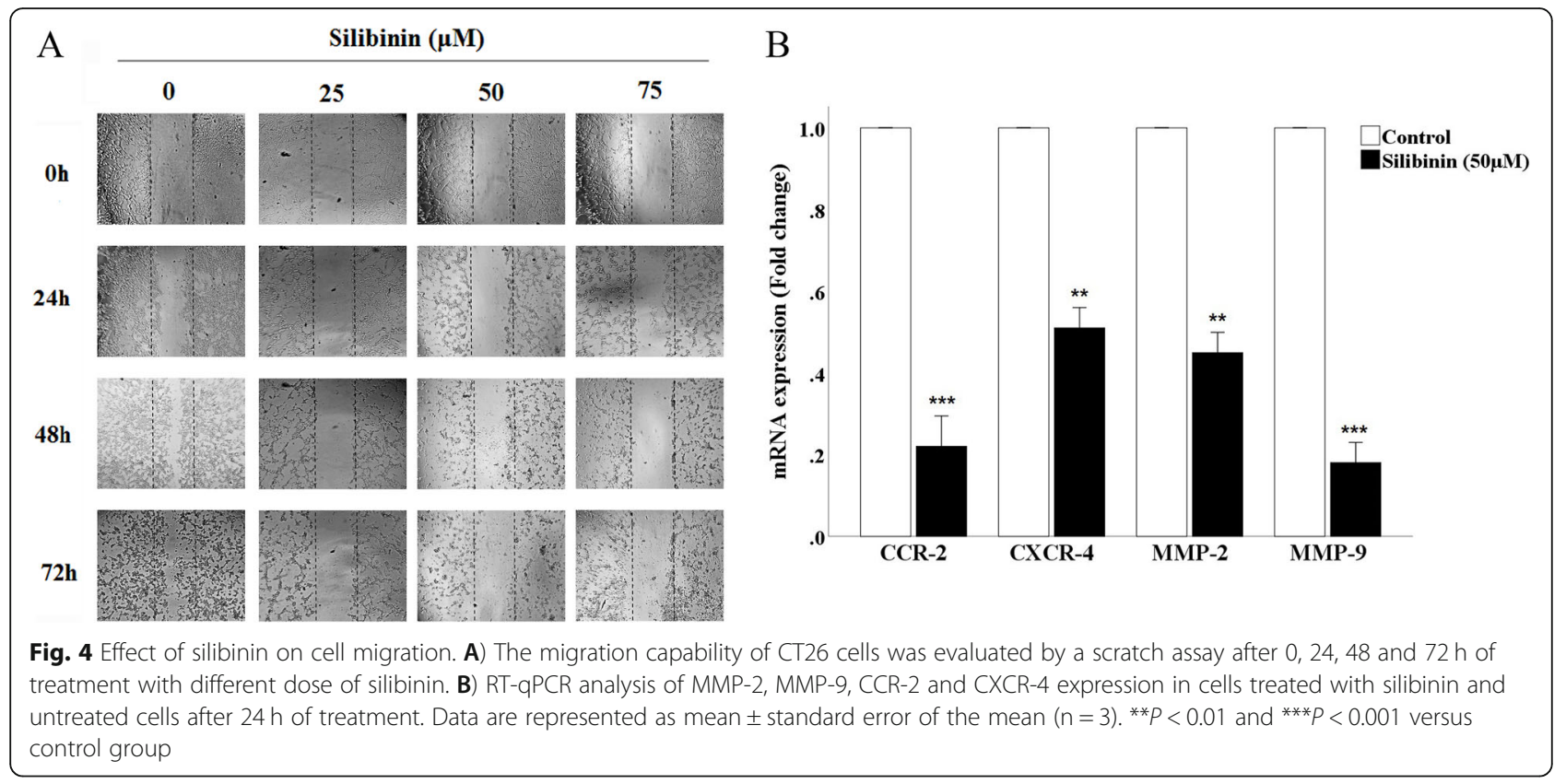

migration of CT26 cells through down-regulation of $M M P-2, M M P-9, C X C R-4$, and CCR-2.

\section{Discussion}

As exhibiting the complete set of hallmarks of cancer is an exclusive characteristic of cancer cells, recent therapeutic approaches have been increasingly aiming to target one or more of these hallmarks. These characteristic have been targeted over the past decade in the development of therapeutic treatments for colorectal cancer as one the most diagnosed and lethal cancers around the world [19]. Silibinin has exhibited anti-cancer properties in different types of tumors [7-9]. In this study we demonstrated the cytotoxic effects of silibinin on four of hallmarks of cancer namely, uncontrolled proliferation, cell survival, induction of angiogenesis and promotion of migration.

Promoting cell death is one effective strategy to overcome unlimited proliferation of cancer cells, as current anti-cancer therapies fail to exert substantial antitumor effects, owing to the aberrant molecular machinery of regulated cell death [20]. Thus, factors capable of inducing both apoptosis and autophagy, as two main pathways of cell death, could be promising candidates for increasing drug sensitivity [21].

Our findings show that silibinin decreased the CT26 cells proliferation in a dose- and time-dependent manner. The antiproliferative and proapoptotic effects of silibinin could be attributed to upregulation of Bax as a proapoptotic gene as well as downregulation of antiapoptotic $\mathrm{Bcl}-2$ gene. In a study conducted by Yagiet al on the testicular cancer cells a significant increase of
P53 in silibinin-treated cells has been demonstrated [22]. In a similar study, it was found that ROS-JNK-P53 cycle was stimulated towards the cell death as well as upregulation of P53 and PUMA expression level and in turn upregulation of $\mathrm{Bcl}-2$ and $\mathrm{Bax}$ in cells treated with silibinin [23]. Furthermore, the results of our study show that silibinin considerably increased Caspase-3 expression, which is consistent with other studies, suggesting that silibinin strongly induced cell cycle arrest and apoptosis through Poly (ADP-ribose) polymerase cleavage, overexpression of $p 15 \operatorname{Ink} 4 b$ and activation of caspase-3/9 and $J N K$ [24-26]. Systemic toxicity, as one of the major concerns in existing cancer treatments, is yet to be resolved. One solution to this issue could be the development of new drugs, having an optimum dose that does not harm normal tissues. Accordingly, the results of this study showed that silibinin appeared to be innocuous to normal cells, as is apparent by its effect on VERO cells [14]. This clearly indicates that silibinin exhibits its cytotoxic property selectively only on cancer cells.

Autophagy, as the second type of programmed cell death (PCD), contributes critically to cellular homeostasis and any disturbances in this process, necessarily, results in interruption of normal cellular functions. The disruption of each stage of autophagy has been seen in many diseases including cancer $[27,28]$. It is commonly known that cell death can be a result of cytoplasmic vacuolation caused by excessive levels of autophagy [29]. In the present study, we showed that silibinin induced autophagy by up-regulating mRNA levels of Atg-5, Atg7, Beclin-1(a necessary factor in early stages of autophagosome formation). Once autophagy is activated, Atg-7 
activates microtubule-associated protein 1-light chain 3I (LC3-I), hence modifying it into its active form ( $L C 3-$ II) [30]. Moreover, Atg-7 has a crucial role in the formation of Atg5-Atg12-Atg16L complex. The exact role of autophagy in cancer progression remains controversial, however most studies suggest that this process acts as tumor suppressor [31]. Similar to our findings, in the study by Jiang et al., the increased levels of Atg12-Atg5 formation, and Beclin-1 in MCF-7 cells treated with silibinin, have been observed. In another study on human fibrosarcoma HT1080, it has been shown that silibinin facilitates apoptosis and cell death by inducing autophagy, via Reactive Oxygen Species (ROS) Pathway [32].

Angiogenesis and migration are two interwoven processes in cancer, both of which are highly affected by hypoxia [33]. Cancer cells undergo hypoxia due to unlimited cell proliferation, enhanced metabolism, and abnormal tumor blood vessels. Hypoxia-inducible factor-1 (HIF-1), a heterodimeric transcriptional factor, plays a crucial regulatory role by mediating cellular adaptation to hypoxia. This molecule constitutes of two subunits; $H I F-1 \alpha$ and $H I F-1 \beta$. The overexpression of HIF-1 $\alpha$ has been observed in many cancers, including CRC [34].

Our findings revealed that silibinin significantly decreased angiogenesis through downregulation of $H I F-1 \alpha$, COX-2, VEGF, Ang-2 and Ang-4. previous studies show that the inhibition of $H I F-1 \alpha$ and $C O X-2$ can effectively decrease tumor angiogenesis and growth [35]. Our results is in agreement with the findings of Kim et al., showing that silibinin inhibits generation of $\mathrm{COX}-2$ through inhibition of the MAPK (Raf/MEK/ERK) signal system [36].

$V E G F$ has a central role in regulation of angiogenesis, which itself is regulated by HIF-1 $\alpha$ [34]. Previous studies showed that silibinin caused concurrent decrease of HIF$1 \alpha$ and VEGF through downregulation of MAPK (ERK1/2) and $A k t$ signaling $[37,38]$. Our findings revealed the decreased level of HIF-1 $\alpha$ and VEGF in CT26 cells treated with silibinin which is likely to have happened through the same pathway.

Moreover, angiopoietins family is among the most important factors in angiogenesis. Angiopoietins are ligands for Tie 2 receptor tyrosine kinases. Of them, Ang-2 stabilizes the existing vasculature in the presence of $V E G F$ and $A n g-4$ stimulates the migration of endothelial cell and tube formation [39, 40]. HIF-1 mediate Ang-2 expression through having a conserved binding site for HIF-1, suggesting that it act as a transcription factor for regulation of Ang-2 [40]. Furthermore, in 2003, Yamakawa et al., suggested that Ang-4 can be upregulated by $H I F-1 \alpha$ under hypoxic condition [41]. Our findings suggest that silibinin probably decreased the Ang-2/4 mRNA expression through downregulation of $V E G F$ and $H I F-1 \alpha$.

Regarding the migration, it has been reported that chemokine/cytokine receptors such as CCR2 and CXCR-4 play key roles in cell migration and metastatic spread in a variety of cancers, including CRC [42]. Our results showed that silibinin decreased the mRNA expression of CCR2 which is in agreement with the findings of

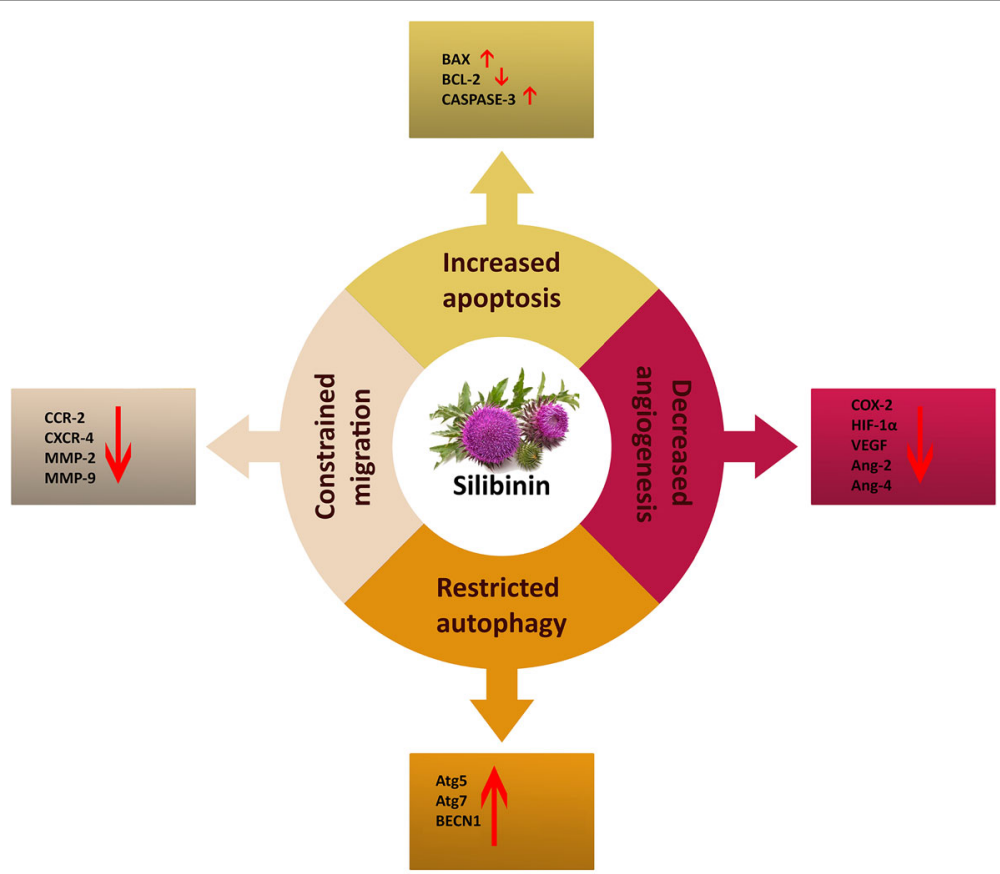

Fig. 5 Schematic representation of anti-tumor effects of silibinin on four hallmarks of CRC 
Forghani et al., on the effects of silibinin on murine breast cancer [43].

Several factors have been identified, having roles in upregulation of CXCR-4 namely, HIF- $1 \alpha$ and VEGF [44]., A study conducted by Wang et al., on breast cancer cells, introduces silibinin as a novel CXCR-4 antagonist, inhibiting chemokine ligand 12-induced migration [45], which supports our findings of decreased levels of CXCR-4 in CT26 cells treated with silibinin.

Furthermore, MMPs are among the major factors affecting migration. By possessing the ability to degrade type IV collagen, MMP2 and MMP-9 facilitate the cell migration and thus metastasis [46]. Interestingly, it has been demonstrated that $M M P-2$ and $M M P-9$ can be activated by CXCR4/CXCL12 axis, hence facilitating metastasis $[47,48]$. On the other hand, a study carried out by $\mathrm{X}$ et al., revealed that the expression of $M M P-2$ and $M M P-9$ can be induced by CCL2/CCR2 axis in nasopharyngeal carcinoma metastasis through $E R K 1 / 2$ pathways. In line with our findings, it has been reported that silibinin downregulates the expression of both $M M P-2$ via Jak2/STAT3 pathway and MMP-9 via the MEK/ERKdependent pathway $[49,50]$.

The protein expression of the genes, investigated in this study were not assessed due to the budget limitation, hence it is recommended that further studies take this under consideration.

In summary, it can be concluded that agents, effecting multi-tumorigenic events exhibit far more promising anti-cancer properties. Silibinin by exerting a wide variety of anti-tumor effects on four of the hallmarks of CRC proves to be a promising potential complementary treatment for existing therapeutic approaches for CRC (Fig. 5).

\section{Acknowledgements}

Not applicable.

\section{Authors' contributions}

All authors contributed to the study conception and design. Rezvan Najafi and Saba Sameri are responsible for the conception and design of the review. Saba Sameri, Chiman Mohammadi and Mehrnaz Mehrabani conducted the literature search, data analysis, and drafted the article. All authors reviewed this draft, contributed and approved the final manuscript.

\section{Funding}

This study was funded by Hamadan University of Medical Sciences under Grant numbers 9811158675.

\section{Availability of data and materials}

The datasets used and/or analysed during the current study are available from the corresponding author on reasonable request.

\section{Declarations}

Ethics approval and consent to participate Not applicable.

\section{Consent for publication}

All the authors approved the version to be published and agreed to be accountable for all aspects of the work.

\section{Competing interests}

The authors declare that they have no competing interests.

\section{Author details}

${ }^{1}$ Research Center for Molecular Medicine, Hamadan University of Medical Sciences, Hamadan, Iran. ${ }^{2}$ Physiology Research Center, Institute of Neuropharmacology, Kerman University of Medical Sciences, Kerman, Iran.

Received: 8 March 2021 Accepted: 18 May 2021

Published online: 31 May 2021

\section{References}

1. Hanahan D. Weinberg RA. Hallmarks of cancer: the next generation cell. 2011;144(5):646-74. https://doi.org/10.1016/j.cell.2011.02.013.

2. Gutschner T, Diederichs $\mathrm{S}$. The hallmarks of cancer: a long non-coding RNA point of view. RNA Biol. 2012;9(6):703-19. https://doi.org/10.4161/rna.20481,

3. Folkman J. Angiogenesis. Annu Rev Med. 2006;57(1):1-18. https://doi.org/1 0.1146/annurev.med.57.121304.131306.

4. Kaur M, Velmurugan B, Tyagi A, Deep G, Kativar S, Agarwal C, et al. Silibinin suppresses growth and induces apoptotic death of human colorectal carcinoma LoVo cells in culture and tumor xenograft. Mol Cancer Ther. 2009;8(8):2366-74. https://doi.org/10.1158/1535-7163.MCT-09-0304.

5. Prasad NR, Muthusamy G, Shanmugam M, Ambudkar SV. South Asian medicinal compounds as modulators of resistance to chemotherapy and radiotherapy. Cancers. 2016;8(3):32. https://doi.org/10.3390/cancers8030032.

6. Montgomery A, Adeyeni T, San K, Heuertz RM, Ezekiel UR. Curcumin sensitizes silymarin to exert synergistic anticancer activity in colon cancer cells. J Cancer. 2016;7(10):1250-7. https://doi.org/10.7150/jca.15690.

7. Singh RP, Dhanalakshmi S, Tyagi AK, Chan DC, Agarwal C, Agarwal R. Dietary feeding of silibinin inhibits advance human prostate carcinoma growth in athymic nude mice and increases plasma insulin-like growth factor-binding protein-3 levels. Cancer Res. 2002:62(11):3063-9.

8. Singh RP, Deep G, Chittezhath M, Kaur M, Dwyer-Nield LD, Malkinson AM, et al. Effect of silibinin on the growth and progression of primary lung tumors in mice. J Natl Cancer Inst. 2006;98(12):846-55. https://doi.org/10.1 093/jnci/dji231.

9. Gu M, Singh RP, Dhanalakshmi S, Agarwal C, Agarwal R. Silibinin inhibits inflammatory and angiogenic attributes in photocarcinogenesis in SKH-1 hairless mice. Cancer Res. 2007;67(7):3483-91. https://doi.org/10.1158/00085472.CAN-06-3955.

10. Half $\mathrm{E}$, Arber N. Colon cancer: preventive agents and the present status of chemoprevention. Expert Opin Pharmacother. 2009;10(2):211-9. https://doi. org/10.1517/14656560802560153.

11. Balachandran C, Sangeetha B, Duraipandiyan V, Raj MK, Ignacimuthu S, AlDhabi $\mathrm{N}$, et al. A flavonoid isolated from Streptomyces sp.(ERINLG-4) induces apoptosis in human lung cancer A549 cells through p53 and cytochrome c release caspase dependant pathway. Chem Biol Interact. 2014;224:24-35. https://doi.org/10.1016/j.cbi.2014.09.019.

12. Olaru OT, Venables L, Van De Venter M, Nitulescu GM, Margina D, Spandidos DA, et al. Anticancer potential of selected Fallopia Adans species. Oncol Lett. 2015;10(3):1323-32. https://doi.org/10.3892/ol.2015.3453.

13. Kwan YP, Saito T, Ibrahim D, Al-Hassan FMS, Ein Oon C, Chen Y, et al. Evaluation of the cytotoxicity, cell-cycle arrest, and apoptotic induction by Euphorbia hirta in MCF-7 breast cancer cells. Pharm Biol. 2016;54(7):1223-36 https://doi.org/10.3109/13880209.2015.1064451.

14. Moradi M, Najafi R, Amini R, Solgi R, Tanzadehpanah H, Esfahani AM, et al. Remarkable apoptotic pathway of hemiscorpius lepturus scorpion venom on CT26 cell line. Cell Biol Toxicol. 2019;35(4):373-85. https://doi.org/10.1 007/s10565-018-09455-3.

15. Sameri S, Saidijam M, Bahreini F, Najafi R. Cancer chemopreventive activities of silibinin on colorectal cancer through regulation of E-cadherin/ $\beta$-catenin pathway. Nutr Cancer. 2020:1-11. https://doi.org/10.1080/01635581.

16. Bai Z-L, Tay V, Guo S-Z, Ren J, Shu M-G. Silibinin induced human glioblastoma cell apoptosis concomitant with autophagy through simultaneous inhibition of mTOR and YAP. Biomed Res Int. 2018:2018:1-10. https://doi.org/10.1155/2018/6165192. 
17. Zheng N, Liu L. Liu W-W, Li F, Hayashi T, Tashiro S-i, et al. crosstalk of ROS/ RNS and autophagy in silibinin-induced apoptosis of MCF-7 human breast cancer cells in vitro. Acta Pharmacol Sin. 2017;38(2):277-89. https://doi.org/1 0.1038/aps.2016.117.

18. Jahanafrooz Z, Motamed N, Rinner B, Mokhtarzadeh A, Baradaran B. Silibinin to improve cancer therapeutic, as an apoptotic inducer, autophagy modulator, cell cycle inhibitor, and microRNAs regulator. Life Sci. 2018;213: 236-47. https://doi.org/10.1016/j.lfs.2018.10.009.

19. Mathonnet M, Perraud A, Christou N, Akil H, Melin C, Battu S, et al. Hallmarks in colorectal cancer: angiogenesis and cancer stem-like cells. World J Gastroenterol: WJG. 2014;20(15):4189-96. https://doi.org/10.3748/ wjg.v20.i15.4189.

20. Thorburn A. Apoptosis and autophagy: regulatory connections between two supposedly different processes. Apoptosis. 2008;13(1):1-9. https://doi. org/10.1007/s10495-007-0154-9.

21. Raina K, Agarwal C, Wadhwa R, Serkova NJ, Agarwal R. Energy deprivation by silibinin in colorectal cancer cells: a double-edged sword targeting both apoptotic and autophagic machineries. Autophagy. 2013;9(5):697-713. https://doi.org/10.4161/auto.23960.

22. Tyagi A, Singh RP, Agarwal C, Agarwal R. Silibinin activates p53-caspase 2 pathway and causes caspase-mediated cleavage of Cip1/p21 in apoptosis induction in bladder transitional-cell papilloma RT4 cells: evidence for a regulatory loop between p53 and caspase 2. Carcinogenesis. 2006;27(11): 2269-80. https://doi.org/10.1093/carcin/bgl098.

23. Fan S, Qi M, Yu Y, Li L, Yao G, Tashiro S-I, et al. P53 activation plays a crucial role in silibinin induced ROS generation via PUMA and JNK. Free Radic Res. 2012:46(3):310-9. https://doi.org/10.3109/10715762.2012.655244.

24. Zhang X, Liu J, Zhang P, Dai L, Wu Z, Wang L, et al. Silibinin induces G1 arrest, apoptosis and JNK/SAPK upregulation in SW1990 human pancreatic cancer cells. Oncol Lett. 2018;15(6):9868-76. https://doi.org/10.3892/ol.2018. 8541.

25. Bayram D, Çetin E, Kara M, Özgöçmen M, Candan I. The apoptotic effects of silibinin on MDA-MB-231 and MCF-7 human breast carcinoma cells. Human \& experimental toxicology. 2017;36(6):573-86. https://doi.org/10.1177/ 0960327116658105.

26. Tyagi A, Agarwal C, Harrison G, Glode LM, Agarwal R. Silibinin causes cell cycle arrest and apoptosis in human bladder transitional cell carcinoma cells by regulating CDKI-CDK-cyclin cascade, and caspase 3 and PARP cleavages. Carcinogenesis. 2004;25(9):1711-20. https://doi.org/10.1093/carcin/bgh180.

27. Liang XH, Jackson S, Seaman M, Brown K, Kempkes B, Hibshoosh H, et al. Induction of autophagy and inhibition of tumorigenesis by beclin 1. Nature. 1999;402(6762):672-6. https://doi.org/10.1038/45257.

28. Yuan J, Lipinski M, Degterev A. Diversity in the mechanisms of neuronal cell death. Neuron. 2003;40(2):401-13. https://doi.org/10.1016/S0896-6273(03 )00601-9.

29. Kondo Y, Kondo S. Autophagy and cancer therapy. Autophagy. 2006;2(2): 85-90. https://doi.org/10.4161/auto.2.2.2463.

30. Kabeya Y, Mizushima N, Yamamoto A, Oshitani-Okamoto S, Ohsumi Y, Yoshimori T. LC3, GABARAP and GATE16 localize to autophagosomal membrane depending on form-II formation. J Cell Sci. 2004;117(13):2805-12. https://doi.org/10.1242/jcs.01131.

31. Rybstein MD, Bravo-San Pedro JM, Kroemer G, Galluzzi L. The autophagic network and cancer. Nat Cell Biol. 2018;20(3):243-51. https://doi.org/10.103 8/s41556-018-0042-2

32. Duan W, Jin X, Li Q. Tashiro S-i, Onodera S, Ikejima T. Silibinin induced autophagic and apoptotic cell death in $\mathrm{HT} 1080$ cells through a reactive oxygen species pathway. J Pharmacol Sci. 2010;113(1):48-56. https://doi. org/10.1254/jphs.09315FP.

33. LV X, Li J, Zhang C, Hu T, Li S, He S, et al. The role of hypoxia-inducible factors in tumor angiogenesis and cell metabolism. Genes \& diseases. 2017; 4(1):19-24. https://doi.org/10.1016/j.gendis.2016.11.003.

34. López-Lázaro M. Hypoxia-inducible factor 1 as a possible target for cancer chemoprevention. Cancer Epidemiol Prev Biomarkers. 2006;15(12):2332-5. https://doi.org/10.1158/1055-9965.EPI-06-0369.

35. Singh RP, Gu M, Agarwal R. Silibinin inhibits colorectal cancer growth by inhibiting tumor cell proliferation and angiogenesis. Cancer Res. 2008;68(6): 2043-50. https://doi.org/10.1158/0008-5472.CAN-07-6247.

36. Kim S, Kim SH, Hur SM, Lee S-K, Kim WW, Kim JS, et al. Silibinin prevents TPA-induced MMP-9 expression by down-regulation of COX-2 in human breast cancer cells. J Ethnopharmacol. 2009;126(2):252-7. https://doi.org/1 0.1016/j.jep.2009.08.032.
37. Fukuda R, Hirota K, Fan F, Do Jung Y, Ellis LM, Semenza GL. Insulin-like growth factor 1 induces hypoxia-inducible factor 1-mediated vascular endothelial growth factor expression, which is dependent on MAP kinase and phosphatidylinositol 3-kinase signaling in colon cancer cells. J Biol Chem. 2002;277(41):38205-11. https://doi.org/10.1074/jbc.M203781200.

38. Chen P-N, Hsieh Y-S, Chiou H-L, Chu S-C. Silibinin inhibits cell invasion through inactivation of both PI3K-Akt and MAPK signaling pathways. Chem Biol Interact. 2005;156(2-3):141-50. https://doi.org/10.1016/j.cbi.2005.08.005.

39. Yamakawa M, Liu LX, Belanger AJ, Date T, Kuriyama T, Goldberg MA, et al. Expression of angiopoietins in renal epithelial and clear cell carcinoma cells: regulation by hypoxia and participation in angiogenesis. A J Physiol-Renal Physiol. 2004;287(4):F649-F57. https://doi.org/10.1152/ajprenal.00028.2004.

40. Simon MP, Tournaire R, Pouyssegur J. The angiopoietin-2 gene of endothelial cells is up-regulated in hypoxia by a HIF binding site located in its first intron and by the central factors GATA-2 and Ets-1. J Cell Physiol. 2008;217(3):809-18. https://doi.org/10.1002/jcp.21558.

41. Yamakawa M, Liu LX, Date T, Belanger AJ, Vincent KA, Akita GY, et al. Hypoxia-inducible factor-1 mediates activation of cultured vascular endothelial cells by inducing multiple angiogenic factors. Circ Res. 2003: 93(7):664-73. https://doi.org/10.1161/01.RES.0000093984.48643.D7.

42. Kurzejamska E, Sacharczuk M, Landázuri N, Kovtonyuk O, Lazarczyk M, Ananthaseshan S, et al. Effect of chemokine (CC motif) ligand 7 (CCL7) and its receptor (CCR2) expression on colorectal Cancer behaviors. Int J Mol Sci. 2019:20(3):686. https://doi.org/10.3390/ijms20030686.

43. Forghani $P$, Khorramizadeh MR, Waller EK. Silibinin inhibits accumulation of myeloid-derived suppressor cells and tumor growth of murine breast Cancer. Cancer med. 2014;3(2):215-24. https://doi.org/10.1002/cam4.186.

44. Oh YS, Kim HY, Song I-C, Yun H-J, Jo D-Y, Kim S, et al. Hypoxia induces CXCR4 expression and biological activity in gastric cancer cells through activation of hypoxia-inducible factor-1a. Oncol Rep. 2012;28(6):2239-46. https://doi.org/10.3892/or.2012.2063.

45. Wang Y, Liang W-C, Pan W-L, Law W-K, Hu J-S, Ip DT-M, et al. Silibinin, a novel chemokine receptor type 4 antagonist, inhibits chemokine ligand 12induced migration in breast cancer cells. Phytomedicine. 2014;21(11):13107. https://doi.org/10.1016/j.phymed.2014.06.018.

46. Webb AH, Gao BT, Goldsmith ZK, Irvine AS, Saleh N, Lee RP, et al. Inhibition of MMP-2 and MMP-9 decreases cellular migration, and angiogenesis in in vitro models of retinoblastoma. BMC Cancer. 2017;17(1):434. https://doi. org/10.1186/s12885-017-3418-y.

47. Tang C-H, Tan T-W, Fu W-M, Yang R-S. Involvement of matrix metalloproteinase-9 in stromal cell-derived factor-1/CXCR4 pathway of lung cancer metastasis. Carcinogenesis. 2008;29(1):35-43. https:/doi.org/10.1093/ carcin/bgm220.

48. Zhang R, Pan X, Huang Z, Weber GF, Zhang G. Osteopontin enhances the expression and activity of MMP-2 via the SDF-1/CXCR4 axis in hepatocellular carcinoma cell lines. PLoS One. 2011;6(8):e23831. https://doi.org/10.1371/ journal.pone.0023831.

49. Byun HJ, Darvin P, Kang DY, Sp N, Joung YH, Park JH, et al. Silibinin downregulates MMP2 expression via Jak2/STAT3 pathway and inhibits the migration and invasive potential in MDA-MB-231 cells. Oncol Rep. 2017 ; 37(6):3270-8. https://doi.org/10.3892/or.2017.5588.

50. Oh S-J, Jung SP, Han J, Kim S, Kim JS, Nam SJ, et al. Silibinin inhibits TPAinduced cell migration and MMP-9 expression in thyroid and breast cancer cells. Oncol Rep. 2013;29(4):1343-8. https://doi.org/10.3892/or.2013.2252.

\section{Publisher's Note}

Springer Nature remains neutral with regard to jurisdictional claims in published maps and institutional affiliations. 